\title{
BITTER PEPTIDES, OCCURRENCE AND STRUCTURE
}

\author{
Y. GUIGOZ and J. SOLMS \\ Dept. of Food Science, Swiss Federal Institute of Technology, 8006 Zurich, Switzerland
}

\begin{abstract}
The bitter taste of many protein rich foods resides in the peptide fraction. 61 bitter tasting peptides, isolated from natural systems, and 145 bitter tasting synthetic peptides are reviewed. The relationships between average hydrophobicity and bitter taste are then discussed.
\end{abstract}

\section{Introduction}

It has long been established that the bitter taste of protein rich foods resides in the peptide fraction, and that the hydrolysis of proteins with proteolytic enzymes is very often accompanied by formation of bitter substances. Murray and Baker (1952) were the first authors interested in the taste of enzymatic protein hydrolysates. They found a bitter taste in enzymatic hydrolyates from casein and lactalbumin, obtained with commercial proteinases, and a neutral taste in corresponding hydrolysates from gelatin. Ichikawa et al. (1959) hydrolysed casein, soy protein, ovalbumin and gluten with a proteinase from Bacillus subtilis and found the development of a bitter taste; a pronounced bitter taste was obtained with casein hydrolysates. Fujimaki et al. (1968b) reported that the hydrolysis of soy protein with different proteinases always results in a bitter tasting hydrolysate, due to the formation of bitter tasting peptides. Cserhati and Hollo (1974) described the formation of bitter tasting peptides, formed through enzymatic breakdown of casein by bacterial proteolytic enzymes. Petritschek et al. (1972) degraded proteins with five different proteolytic enzymes; a pronounced bitter taste was obtained with casein, soy protein, zein, gliadin and proteins of the lactoserum, while serum albumin, gluten and gelatin did not give a bitter note. Apparently, the substrate is of prime importance, and casein gives most bitter hydrolysates. The proteolytic enzymes applied play only a secondary rôle. Therefore the primary structure of the proteins serving as substrates for the enzymes and the amino acid composition of formed peptides are most important factors.

\section{Average Hydrophobicity and Bitter Taste}

Ney (1971) examined the relationships between the average hydrophobicity $(Q)$ of many peptides and the bitter taste of these compounds, as reported in the literature. He based his studies on the data published by Tanford (1962, 1972). Tanford (1962) has shown that the hydrophobicity of amino acids, peptides and proteins can be assessed from solubility data of free amino acids. If the solubility for phenylalanine, for example, is $\mathrm{N}_{\mathrm{HOH}}$ in water, and $\mathrm{N}_{\mathrm{EtOH}}$ in ethyl alcohol, then the free energy of transferring one mole of phenylalanine from an aqueous solution (at a certain concentration) to an ethanolic solution (at the same concentration) is, apart from activity 
coefficients :

$$
\Delta F_{t}=-\mathrm{RT} \ln \frac{\mathrm{N}_{\mathrm{EtOH}}}{\mathrm{N}_{\mathrm{HOH}}},
$$

$\Delta F_{r}$, the transfer free energy, is a roughly additive function of molecular structure, that is of the different parts of the molecule:

$$
\Delta F_{t}=\sum \Delta f_{t} .
$$

For phenylalanine it can be regarded as the sum of two terms, one for the benzyl side chain and one for the dissociated backbone. The transfer free energy for the backbone must be similar to that for glycine, which is determined by the use of Equation (1) with glycine solubility data. Subtraction therefore leads to a transfer free energy for the side chain itself (Bigelow, 1967):

$$
\Delta f_{t R}=\Delta F_{t}-\Delta f_{t s \text { lycine }}
$$

where:

$$
\begin{aligned}
\Delta f_{t R} & =\text { transfer free energy for the side chain, } \\
\Delta F_{t} & =\text { transfer free energy for the amino acid, } \\
\Delta f_{\text {g glycine }} & =\text { transfer free energy for glycine. }
\end{aligned}
$$

Tanford (1962) and Nozaki and Tanford (1971) calculated the transfer free energies of the side chains of amino acids; the data are presented in Table I. Dunhill (1965) introduced the expression 'hydrophobicity' for these values.

Based on these data, Bigelow (1967) and Ney (1971) introduced a new parameter for peptides and proteins, the average hydrophobicity $(Q)$, which is obtained as follows:

$$
Q=\frac{\sum \Delta f_{t R}}{n}\left(\mathrm{cal} \mathrm{res}^{-1}\right),
$$

where $n=$ number of amino acid residues.

Ney (1971) proposed the following hypothesis, which will be called 'Ney's rule' in this paper:

- all peptides having low average hydrophobicities, $1300 \mathrm{cal} \mathrm{res}^{-1}$ or lower, are not bitter in taste;

- all peptides having high average hydrophobicities, $1400 \mathrm{cal} \mathrm{res}^{-1}$ or higher, are bitter in taste;

- the sequences of the amino acids in the peptides have no influence on the bitter taste.

Ney (1972), in applying his theory to proteins, calculates an average hydrophobicity of total protein molecules. The $Q$-value obtained permits an evaluation of the bitterness of the corresponding protein hydrolyzates. Average hydrophobicities $(Q)$ for several proteins are reported in Table II.

It has not been reported in the literature that an enzymatic hydrolysis of collagen or beef muscle (meat proteins) bave ever given a bitter tasting hydrolysate. On the other 
TABLE I

Hydrophobicity of the side chains of amino acids

\begin{tabular}{lcc}
\hline & $\begin{array}{l}\text { After Tanford } \\
(1962) \\
\Delta F_{t} \text { (cal) }\end{array}$ & $\begin{array}{l}\text { After Nozaki } \\
\text { and Tanford (1971) b } \\
\Delta F_{t} \text { (cal) }\end{array}$ \\
\hline $\begin{array}{l}\text { Tryptophan } \\
\text { Isoleucine }\end{array}$ & 3000 & 3400 \\
Tyrosine & 2970 & \\
Phenylalanine & 2870 & 2300 \\
Proline & 2650 & 2500 \\
Leucine & 2600 & 1800 \\
Valine & 2420 & 1500 \\
Lysine & 1690 & 1300 \\
Methionine & 1500 & 500 \\
Alanine & 1300 & \\
Arginine & 730 & 500 \\
Histidine & 730 & \\
Glutamic acid & 550 & 400 \\
Aspartic acid & 540 & -300 \\
Threonine & 440 & 0 \\
Serine & 40 & \\
Glycine & 0 & \\
Asparagine & -10 & \\
Glutamine & -100 & \\
\hline
\end{tabular}

- Hydrophobicity calculated from free energy of transfer from ethanol to water.

b Hydrophobicity calculated from free energy of transfer from ethanol and dioxane solutions to water.

TABLE II

Average hydrophobicities of several proteins after Ney (1972)

\begin{tabular}{ll}
\hline & $\begin{array}{l}Q \\
\left(\text { cal res }^{-1}\right)\end{array}$ \\
\hline casein & 1605 \\
zein & 1480 \\
soy protein & 1540 \\
meat protein & 1300 \\
collagen & 1280 \\
\hline
\end{tabular}

side there is ample evidence that all proteins giving bitter tasting enzymatic hydrolysates have a high average hydrophobicity (Ney, 1972; Petritschek et al., 1972).

Bigelow (1967) has published a list with average hydrophobicities $(Q)$ for 150 proteins; the values vary from 440 to $2020 \mathrm{cal} \mathrm{res}^{-1}$ Belitz (1973) discussed relationships between structure, taste and hydrophobicity of bitter peptides. 


\section{Occurrence of Bitter Tasting Peptides}

In this section the bitter tasting peptides described in the literature are listed and discussed. The average hydrophobicities $\left(Q, \mathrm{cal} \mathrm{res}^{-1}\right)$ of many of these peptides were calculated according to Ney (1972), using the data from Tanford (1962), and are also listed. Peptides with an average hydrophobicity of $Q<1300$ cal res $^{-1}$ having a bitter taste are marked with an asterisk (*).

\subsection{BITTER PEPTIDES FROM CASEIN}

Carr et al. (1956) studied the bitter taste of enzymatic hydrolysates obtained from $\alpha$-, $\beta$ - and $\gamma$-casein; they isolated a bitter peptide composed of Asp, Glu, Gly, Ala, Val, Pro, Tyr and Leu. This peptide did not react with ninhydrin; therefore a cyclic $\mathrm{N}$ terminal structure was proposed with the following C-terminal sequence: -Leu-ValGlu-Leu-OH.

Gordon and Speck (1965) isolated several bitter peptides from skim milk cultures of certain strains of lactic bacteria. One compound has been characterized by Sullivan et al. (1971), and has the following structure, which corresponds to the residues 194209 of the C-terminal sequence of $\beta$-casein (Ribadeau-Dumas et al., 1972).

(1) pyroglutamic acid-Gin-Pro-Val-Leu-Gly-Pro-Val-Arg-Gly-Pro-Phe-Pro-Ile-IleVal-OH $(Q=1700)$.

Matoba et al. (1970) described the isolation of three bitter peptides from a tryptic hydrolysate of casein. The peptides have the following structure:

(2) H-Gly-Pro-Phe-Pro-Val-Ile-OH $(Q=2085)$.

(3) H-Phe-Phe-Val-Ala-Pro-Phe-Pro-Glu-Val-Phe-Gly-Lys-OH $(Q=1830)$.

(4) H-Phe-Ala-Leu-Pro-Gln-Tyr-Leu-Lys-OH $(Q=1898)$.

Peptide (2) corresponds approximately to the residues 203-209 of $\beta$-casein, and peptide (3) corresponds to the residues 23-34 of $\alpha_{31}$-casein (Mercier et al., 1971). Belitz and Sparrer (1971) and Sparrer and Belitz (1975) obtained two peptides (5) and (6) from a total hydrolysate of casein with chymotrypsin, and a peptide (7) using trypsin as enzyme. The peptides have the following structure:

(5) H-Phe-Tyr-Pro-Glu-Leu-Phe-OH $(Q=2290)$.

(6) H-Val-Glu-Val-Phe-Ala-Pro-Pro-Phe-OH $(Q=1895)$.

(7) H-Phe-Phe-Val-Ala-Pro-Phe-Pro-Glu-Val-Phe-Gly-Lys-OH $(Q=1830)$.

Peptide (5) has been further degraded to (8) and (9) with the action of thermolysine:

(8) H-Phe-Tyr-Pro-Glu-OH $(Q=2167)$.

(9) H-Leu-Phe-OH $(Q=2535)$.

The peptides (8) and (9) are also very bitter. Peptide (7) is identical with peptide (3) described by Matoba et al. (1970). Peptide (5) corresponds to the residues 145-150 of $\alpha_{\mathbf{s} 1}$-casein (Mercier et al., 1971).

Two bitter peptides, isolated from an enzymatic hydrolysate of casein with alkaline protease from Bacillus subtilis, have been described by Minamiura et al. (1972a, 1972b):

(10) H-Arg-Gly-Pro-Pro-Phe-Phe-Ile-Val-OH $\quad(Q=1891)$. 
(11) Cyclo (Trp-Leu-Trp-Leu).

The bitter taste of the peptide (10) was not influenced by a specific elimination of the terminal amino acids Arg, Val or Val+Ile. However, an elimination of Arg + Gly removed the bitterness. Shiba and Nunami (1974) showed that the peptide (11) was a diketopiperazine:

(11) Cyclo (Leu-Trp).

Peptide (10) corresponds to the C-terminal sequence of $\beta$-casein, and peptide (11) to the C-terminal sequence of $\alpha_{11}$-casein (Mercier et al., 1971).

In studying the action of rennin on casein, Pélissier et al. (1974) isolated six bitter peptides. The structures of the peptides, assigned after comparison with the amino acid sequences of corresponding casein fractions, are as follows.

Assigned to $\beta$-casein:

(12) H-Phe-Leu-Leu-OH (residues 190-192) $(Q=2497)$.

Assigned to $\alpha_{31}$-casein :

(13) H-Leu-Arg-Phe-OH (residues 21-23) $(Q=1933)$.

(14) H-Val-Pro-Leu-Gly-Thr-GIn-Tyr-Thr-Asp-Ala-Pro-Ser-Phe-OH (residues 167-179) $(Q=1309)$.

(15) H-Pro-Gln-Val-Phe-OH (residues 29-32 ( $Q=1735)$.

(16) H-Ala-Tyr-Phe-Tyr-Pro-Glu-Leu-OH (residues 143-149 ( $Q=2099)$.

(17) H-Leu-Arg-Leu-OH (residues 99-101) $(Q=1857)$.

Mercier et al. (1971), Ribadeau-Dumas et al. (1972) and Pelissier et al. (1974) isolated another series of bitter tasting peptides during studies of casein. From $\alpha_{31}$-casein they obtained the following peptides:

(18) H-Leu-Gly-Tyr-Leu-Glu-Gln-Leu-Leu-OH (residues 92- 99) ( $Q=1638)$.

(19) H-Phe-Tyr-Pro-Glu-Leu-Phe-Arg-OH (residues 145-151) $(Q=2067)$.

(20) H-Phe-Phe-Val-Ala-Pro-Phe-Pro-Gln-Val-

Phe-Gly-Lys-OH

Studies with $\beta$-casein led to the compounds

(21) H-Ala-Pro-Lys-OH

(22) H-Gly-Pro-Phe-Pro-Ile-Ile-Val-OH (residues 23-34) $(Q=1784)$.

(residues 103-105) $(Q=1610)$.

(residues 203-209) $(Q=2211)$.

The peptide (20) has also been described by Matoba et al. (1970) and by Sparrer and Belitz (1975). The peptide (22) ressembles structurally to the peptide (2) after Matoba et al. (1970). The action of papain on casein liberates a bitter peptide corresponding to the residues 53-79 of $\beta$-casein, as reported by Clegg et al. (1974):

(23) H-Ala-Gln-Thr-Gln-Ser-Leu-Val-Tyr-Pro-Phe-Pro-Gly-Pro-

Ile-Pro-Asn-Ser-Leu-Pro-Gin-Asn-Ile-Pro-Pro-Leu-Thr-

$\mathrm{Gln}-\mathrm{OH}$

$(Q=1493)$.

Hill and Van Leeuwen (1974) isolated three bitter peptides from a tryptic hydrolysate of casein, having the following structures:

(24) H-Phe-Phe-Val-Ala-Pro-Phe-Pro-Gln-Val-Phe-Gly-Lys-OH

$(Q=1784)$.

(25) H-Tyr-Leu-Gly-Tyr-Leu-Glu-Gln-Leu-Leu-Arg-OH

$(Q=1670)$.

(26) H-Phe-Tyr-Pro-Glu-Leu-Phe-Arg-OH

$(Q=2067)$.

These peptides are fragments from $\alpha_{31}$-casein (Mercier et al., 1971); peptide (25) 
corresponds to the residues $23-34$, peptide $(26)$ to $(91)-(100)$ and peptide $(27)$ to (145)-(151).

From all the above mentioned 26 peptides, 16 (eventually 17) are fragments of $\alpha_{31}$ casein, and 5 (eventually (7)) those of $\beta$-casein. Two peptides, however, cannot be located; they probably are fragments from still unknown fractions. Therefore it cannot be stated that bitter peptides are always derived from $\alpha_{s 1^{-}}$and $\beta$-casein.

\subsection{BITTER PEPTIDES FROM SOY PROTEIN}

Most enzymatic hydrolyzates of soy protein are bitter in taste (Fujimaki et al., 1971a); this is probably due to the formation of bitter tasting peptides. Fujimaki et al. (1968a, 1970) and Yamashita et al. (1969) have isolated a series of eight bitter peptides from a soy protein hydrolysate, using pepsin as enzyme:

(27) $\mathrm{H}-\mathrm{Gly}$-Leu-OH

$(Q=1210)^{*}$.

(28) H-Leu-Phe-OH

$(Q=2535)$.

(29) H-Ser-Lys-Gly-Leu-OH

$(Q=990)$.*

(30) H-Leu-Lys-OH

$(Q=1960)$.

(31) H-Phe-(Ile, Leu ${ }_{2}$-GIn-Gly-Val-OH

$(Q=1736)$.

(32) H-Arg-Leu-Leu-OH

$(Q=1875)$.

(33) $\mathrm{H}$-Arg-Leu-OH

$(Q=1575)$.

(34) pyroglutamic acid-Gly-Ser-Ala-Ile-Phe-Val-Leu-OH

$(Q=1313)$

Peptide (34) is ninhydrin negative.

The authors underline the importance of leucine as $\mathrm{N}$-terminal or C-terminal amino acid. Arai et al. (1970) isolated a nondialysable bitter peptide from a pepsin hydrolysate of soy protein:

(35) H-Phe-(Arg, Asp 2 , Glu 2 , Gly, lle, Leu, Lys 2 , Pro-Ser-Thr)-Trp-

(Ala, Arg, Asp, Gly, Val)-Gln-Tyr-Phe-Leu-OH $\quad(Q=1319)$.

On treatment with $\mathrm{N}$-bromosuccinimide, this peptide liberates a bitter nonapeptide:

(36) H-(Ala, Arg, Asp, Gly, Val)-Gln-Tyr-Phe-Leu-OH

$(Q=1292)$.

On further treatment with carboxypeptidase, the bitterness of peptide (36) decreases; therefore the authors stress the importance of the C-terminal sequence-Tyr-Phe-Leu$\mathrm{OH}$ as a center for inducing bitter taste.

In order to decrease the bitter taste of enzymatic soy protein hydrolyzates, several authors propose a 'resynthesis' of larger peptides by chymotrypsin in neutral medium with the 'plastein reaction' (Fujimaki et al., 1970a; Yamashita et al., 1970). This treatment gives an agreeable brothy taste, probably due to the formation of peptides rich in glutamic acid. However, Arai et al. (1972) isolated from such a reaction mixture also a bitter peptide:

(37) H-Glu-Phe-OH

$$
(Q=1600)
$$

\subsection{BITTER PEPTIDES FROM ZEIN}

Several bitter peptides were isolated from a zein hydrolysate, using pepsin as enzyme (Wieser and Belitz, 1973):

(38) H-Ala-Ile-Ala-OH

$(Q=1477)$. 
(39) H-Ala-Ala-Leu-OH

$(Q=1293)^{*}$.

(40) H-Gly-Ala-Leu-OH

$\left(Q=1050^{*}.\right)$

(41) H-Leu-Gln-Leu-OH

$(Q=1613)$.

(42) H-Leu-Glu-Leu-OH

$(Q=1797)$.

(43) H-Leu-Val-Leu-OH

$(Q=2177)$.

(44) H-Leu-Pro-Phe-Asn-Gln-Leu-OH

$(Q=1682)$.

(45) H-Leu-Pro-Phe-Ser-Gln-Leu-OH

$(Q=1688)$.

From this series the peptide (42) was obtained after partial hydrolysis of peptide (41).

\subsection{BitTER PEPTIDES ISOLATED FROM DIFFERENT FOODS}

Many bitter peptides have been obtained from enzymatic protein hydrolysates; however, only a few have been isolated from foods rich in proteins. Raadsveld (1953) isolated a bitter peptide from Gouda cheese, composed of Pro, Phe and other aliphatic amino acids. Zvyagintsev et al. (1972) separated and characterized several bitter peptides from different Russian cheese varieties. They all contained Leu, Val, and Phe, and a cyclic $\mathrm{N}$-terminal structure was reported as an important feature. Hodges et al. (1972), Richardson and Creamer (1973), Hamilton et al. (1974) separated and characterized the following bitter peptides from Cheddar cheese:

(46) H-Glu-Val-Leu-Asn-OH

(47) H-Asn-Glu-Asn-Leu-Leu-OH

$(Q=1165)^{*}$.

(48) H-Ala-Pro-Phe-Pro-Glu-Val-Phe-OH

$(Q=1087)^{*}$.

(49) H-Gln-Asp-Lys-Ile-His-Pro-Phe-Ala-Gln-Thr-Gln-Ser-LeuVal-Tyr-Pro-Phe-Pro-Gly-Pro-lle-Pro-OH$$
(Q=1984) \text {. }
$$

$(Q=1521)$.

The peptides (46), (47), (48) and (49) correspond to the residues 14-17, 17-21 and 26-33 of $\alpha_{31}$-casein, and 46-67 of $\beta$-casein, respectively. Guigoz et al. (1974) isolated a bitter peptide from a Swiss mountain cheese with the following structure

(50) H-Leu-Trp-OH

$(Q=2710)$.

which corresponds to the residues 198-199, the C-terminal end of the $\alpha_{51}$-casein. Huber et al. (1974) isolated from Butterkäse the peptide:

(51) H-Pro-Phe-Pro-Gly-Pro-Ile-Pro-Asn-Ser-OH $(Q=1844)$ which corresponds to the residues $61-69$ of $\beta$-casein.

A cyclic bitter dipeptide occurs in Japanese Saké, as reported by Takahashi et al. (1974):

(52) cyclo (Pro-Leu).

Other diketopiperazines are important bitter principles in roasted cocoa, as reported by Pickenhagen (1974):

(53) cyclo (Pro-Leu).

(54) cyclo (Val-Phe).

(55) cyclo (Pro-Phe).

(56) cyclo (Pro-Gly).

(57) cyclo (Ala-Val).

(58) cyclo (Ala-Gly). 
(59) cyclo (Ala-Phe).

(60) cyclo (Phe-Gly).

(61) cyclo (Pro-Asn).

They are formed during the roasting of cocoa and exhibit a synergistic increase in bitterness together with theobromine.

\subsection{SYNTHETIC BITTER PEPTIDES}

Several authors studied the bitter taste sensation of synthetic peptides in order to find a relationship between structure and taste.

Kirimura et al. (1969) tested the series of dipeptides listed below; they all exhibit a bitter taste in $0.2 \%$ aqueous solutions.
(62) H-Gly-Ile-OH
$(Q=1485)$.
(70) H-Val-Leu-OH
$(Q=2055)$.
(63) H-Gly-Met-OH
$(Q=650)$.*
(71) H-Leu-Gly-OH $(Q=1210)^{*}$.
(64) H-Gly-Phe-OH
$(Q=1325)$.
(72) H-Leu-Leu-OH
$(Q=2420)$.
(65) H-Ala-Phe-OH
$(Q=1690)$.
(73) H-Leu-Tyr-OH
$(Q=2645)$.
(66) $\mathrm{H}$-His-His-OH
(74) H-Lys-Gly-OH $(Q=750)^{*}$.
(67) H-Arg-Pro-OH
$(Q=1665)$.
(75) H-Lys-Ala-OH
$(Q=1115)^{*}$.
(68) H-Val-Ala-OH
$(Q=1210)^{*}$.
(76) H-Val-Val-Val-OH $(Q=1690)$.
(69) H-Val-Val-OH
$(Q=1690)$.
(77) H-Gly-Trp-OH
$(Q=1500)$.

The authors relate a bitter taste with the following structural requirements for dipeptides:

- two neutral amino acids with large alkyl groups $(C \geqslant 3)$,

- one neutral amino acid with a large alkyl group $(C \geqslant 3)$ and one neutral amino acid with a short alkyl group $(C \leqslant 3)$,

- one neutral amino acid and one aromatic amino acid,

- one neutral amino acid and one basic amino acid.

In relation with the bitter taste of a nondialysable peptide from soy protein hydrolysates, Arai et al. (1970) tested the bitter taste of the following synthetic peptides and peptide derivatives:

$\begin{array}{lll}\text { (78) H-Tyr-Phe-Leu-OH } & \text { (very bitter) } & (Q=2647) \text {. } \\ \text { (79) H-Phe-Leu-OH } & \text { (very bitter) } & (Q=2535) \\ \text { (80) H-Tyr-Phe-OH } & \text { (bitter) } & (Q=2760) \\ \text { (81) Ac-Tyr-Phe-Leu-OH } & \text { (very bitter) } & \\ \text { (82) Ac-Phe-Leu-OH } & \text { (bitter) } & \\ \text { (83) Ac-Tyr-Phe-OH } & \text { (bitter) } & \\ \text { (84) H-Tyr-Phe-Leu-OEt } & \text { (not bitter) } & \\ \text { (85) H-Phe-Leu-OEt } & \text { (not bitter) } & \\ \text { (86) H-Tyr-Phe-OEt } & \text { (not bitter) } & \end{array}$

The authors conclude that an acetylation diminishes, and an ethylation eliminates the bitter taste of dipeptides.

Arai et al. (1973) further studied the taste of twelve glutamyl-dipeptides. They found that the corresponding dipeptides with acid, polar and hydrophilic groups exhibit a brothy taste, while hydrophobic amino acids introduce a bitter taste; dipeptides with 
intermediate structural elements have no taste. The following peptides exhibited a bitter taste:
(87) $\mathrm{H}$-Glu-Ile-OH
$(Q=1760)$.
(89) H-Glu-Tyr-OH
$(Q=1710)$.
(88) H-Glu-Leu-OH
$(Q=1485)$.
(90) H-Glu-Phe-OH $\quad(Q=1600)$.

In order to investigate the relationship between hydrophobicity and taste of peptides, the authors prepared derivatives of the tripeptide Glu-Gly-Ser and tested the taste as follows:

(91) H-Glu-Gly-Ser-OH

(92) H-Glu-Gly-O-Ac-Ser-OH

(brothy taste)

(93) H-Glu-Gly-O-Bu-Ser-OH

(no taste)

(bitter taste)

They come to the conclusion that acid, hydrophilic glutamyl-oligopeptides exhibit an agreeable brothy flavor, which is diminished with increasing hydrophobicity.

Fujimaki et al. (1972a) observed that the dipeptide H-Glu-Tyr-OH (89) has a bitter taste below $\mathrm{pH} 10$, and no bitter taste above this $\mathrm{pH}$, which coincides with the dissociation of the phenolic $\mathrm{OH}$-group. They attribute the loss in bitterness to the increased hydrophilic properties of the peptide. The analog compound H-Glu-Phe-OH (90) is bitter over the whole $\mathrm{pH}$-range.

Shiraishi et al. (1973) published results on the taste of proline containing di- and tri-peptides. They differentiated between three groups, one with most bitter tasting peptides, containing proline and phenylalanine:

Group I, slightly bitter peptides:
(94) H-Pro-Gly-OH
$(Q=1300)$.
(97) H-Ala-Pro-OH
$(Q=1665)$.
(95) H-Gly-Pro-OH
$(Q=1300)$.
(98) H-Pro-Pro-OH
$(Q=2600)$.
(96) H-Pro-Ala-OH
$(Q=1665)$.
(99) H-Val-Val-OH
$(Q=1690)$.

Group II, bitter peptides:
(100) H-Val-Pro-OH
$(Q=2145)$.
(101) H-Pro-Val-OH
$(Q=2145)$.
(102) H-Leu-Pro-OH
$(Q=2510)$.
(103) H-Pro-Leu-OH
$(Q=2510)$.
(104) H-Ile-Pro-OH
$(Q=2785)$.
(105) H-Pro-Ile-OH
$(Q=2785)$.

(106) H-Tyr-Pro-OH

$(Q=2735)$.

(107) H-Pro-Tyr-OH

$(Q=2735)$.

(108) H-Lys-Pro-OH

$(Q=2050)$.

(109) H-Arg-Pro-OH

$(Q=1665)$.

(110) H-Pro-Phe-OH

$(Q=2625)$.

(111) H-Gly-Leu-OH

$(Q=1210)^{*}$.

Group III, very bitter peptides:
(112) H-Phe-Pro-OH $\quad(Q=2625)$.
(113) H-D-Phe-Pro-OH
(115) H-Gly-Phe-Pro-OH $(Q=1750)$.
(116) H-Phe-Pro-Gly-OH $(Q=1750)$.

(114) H-Pro-D-Phe-OH

Most interesting are differences in bitterness between these peptides due to the sequence of the amino acids. The peptide H-Pro-Phe-OH (110) is less bitter than the peptide H-Phe-Pro-OH (112); and the peptide H-Gly-Phe-Pro-OH (115) is more bitter than the peptide $\mathrm{H}$-Phe-Pro-Gly-OH (116). And the two latter peptides are less bitter than the peptide H-Phe-Pro-OH (112). The peptide exhibiting the strongest bitter taste is H-D-Phe-Pro-OH (113).

A very systematic study on relationships between bitter taste and structure has been 
published by Matoba et al. (1972). They propose three groups of bitter tasting peptides and derivatives, namely:

Group I, bitter peptides containing glycine:
(117) H-Gly-Ile-OH $\quad(Q=1485)$.
(126) H-Gly-Pro-OH $\quad(Q=1300)$.
(118) H-Ile-Gly-OH $(Q=1485)$.
(127) H-Pro-Gly-OH $\quad(Q=1300)$.
(119) H-Gly-Ile-Gly-OH $(Q=990) *$.
(128) H-Gly-Pro-Gly-OH $(Q=867)^{*}$.
(120) H-Gly-Leu-OH $\quad(Q=1210)^{*}$.
(129) H-Gly-Tyr-OH $\quad(Q=1435)$.
(121) H-Leu-Gly-OH $(Q=1210)^{*}$.
(130) H-Tyr-Gly-OH $\quad(Q=1435)$.
(122) H-Gly-Leu-Gly-OH $(Q=807)^{*}$.
(131) H-Gly-Tyr-Gly-OH $(Q=957)^{*}$.
(123) H-Gly-Phe-OH $\quad(Q=1325)$.
(132) H-Gly-Val-OH $\quad(Q=845)^{*}$.
(124) H-Phe-Gly-OH $\quad(Q=1325)$.
(133) H-Val-Gly-OH $\quad(Q=845)^{*}$.
(125) H-Gly-Phe-Gly-OH $(Q=883)^{*}$.
(134) H-Gly-Val-Gly-OH $(Q=563)^{*}$.

Group II, derivatives of amino acids with bitter taste
(135) Ac-Leu-OH
(142) H-Tyr-OMe
(136) H-Leu-OMe
(143) N-Ac-Tyr-OMe
(137) Ac-Leu-OMe
(144) Ac-Phe-OH
(138) Ac-Ile-OH
(145) H-Phe-OMe
(139) H-Ile-OMe
(146) Ac-Phe-OMe
(140) Ac-Ile-OMe
(147) Ac-Val-OMe

(141) N-Ac-Tyr-OH

Group III, bitter peptides containing leucine and phenylalanine:

(148) H-Leu-Leu-OH

(151) H-Phe-Leu-OH

(149) H-Leu-Phe-OH

(152) H-Phe-Phe-OH

(150) H-D-Phe-Leu-OH

Further work with derivatives of dipeptides of group III gave the following results. An acetylation decreases the bitterness; a methylation, a methylation and acetylation, and a cyclization all increase the bitterness. Diketopiperazines were the most bitter forms of all dipeptides. The results were then summarized as follows:

- the bitterness of amino acids is increased, if the $-\mathrm{NH}_{2}$ and $-\mathrm{COOH}$ groups are present as derivatives,

- peptides containing hydrophobic amino acids are bitter,

- sequence and configuration of amino acids have no influence on the bitterness of a peptide.

Ney (1971) tested large series of synthetic peptides and published the following list of bitter tasting compounds:
(153) H-Leu-Met-OH $\quad(Q=1860)$.
(161) H-Gly-Ile-OH
$(Q=1485)$.
(154) H-Met-Leu-OH $(Q=1860)$.
(162) H-Gly-Phe-OH
$(Q=1325)$.
(155) H-Leu-Tyr-OH
$(Q=2645)$.
(163) H-Gly-Trp-OH
$(Q=1500)$.
(156) $\mathrm{H}$-Leu-Leu-OH
$(Q=2420)$.
(164) H-Ala-Phe-OH
$(Q=1690)$.
(157) H-Arg-Pro-OH
$(Q=1665)$.
(165) H-Val-Val-OH
$(Q=1690)$.
(158) H-Asp-Phe-OH
$(Q=1595)$.
(166) H-Glu-Phe-OH
$(Q=1600)$.
(159) H-Asp-Tyr-OH
$(Q=1705)$.
(167) H-Glu-Tyr-OH
$(Q=1710)$.
(160) H-Val-Leu-OH
$(Q=2055)$.
(168) H-Ala-Leu-OH
$(Q=1575)$. 
(169) H-Ile-Ala-Met-Glu-Lys-OH

$(Q=1410)$.

(170) H-Ser-Pro-Pro-Pro-Gly-OH

$(Q=2028)$.

Shiba et al. (1974) was interested in diketopiperazines, containing leucine or tryptophane as a component. The compounds are listed in the order of decreasing bitterness:

(171) cyclo (Leu-Trp).

(172) cyclo (Trp-Trp).

(174) cyclo (Leu-Leu).

(173) cyclo (Trp-Gly).

(175) cyclo (Leu-Gly).

In connection with their work on the sweet tasting compound H-Asp-Phe-OMe, Mazur et al. (1969) investigated the taste characteristics of numerous peptides and their derivatives, and found interesting relationships, which, however, cannot be treated in detail in this paper. The following list is just a summary of tested compounds having a bitter taste:

(176) H-Asp-Phe-OH

(177) H-Ala-Phe-OMe

(178) H-His-Phe-OMe

(179) H-Asp-Tyr-OH

(180) H-Ile-Phe-OMe

(181) H-Leu-Phe-OMe

(182) H-Lys-Phe-OMe

(183) H-Phe-Phe-OMe

(184) H-Pro-Phe-OMe

(185) H-Ser-Phe-OMe

(186) H-Thr-Phe-OMe

(187) H-Trp-Phe-OMe

(188) H-Tyr-Phe-OMe

(189) H-Val-Phe-OMe

(190) H-Asp-Ala-OMe

(191) H-Asp-Gly-OMe
$(Q=1595)$.

$$
(Q=1705)
$$

(192) H-Asp-Ile-OMe

(193) H-Asp-Leu-OMe

(194) H-Asp-Trp-OMe

(195) H-Asp-D-Trp-OMe

(196) H-Asp-Val-OMe

(197) H-Glu-Tyr-OMe

(198) H-Asp-Phe-NHMe

(199) H-L-Asp-D-Phe-OMe

(200) H-Asp-Phe- $\mathrm{NMe}_{2}$

(201) H-Asp-Phe-NHNH

(202) H-D-Asp-D-Phe-OMe

(203) H-Asp-Tyr-NHMe

(204) H-Asp-Phe-NHNMe

(205) H-D-Asp-L-Phe-OMe

(206) H-Asp-Tyr-NMe

\section{Discussion}

It can be seen from this compilation that 'Ney's rule' can be applied to the majority of bitter peptides known. Only several peptides containing glycine residues do not comply with this rule. However, if glycine is not considered to be a residue and is not accounted for in the calculations, then most of the peptides have average hydrophobicities ranging higher than $1300 \mathrm{cal} \mathrm{res}^{-1}$. Leaving aside peptides with one or several glycine residues, there are only three peptides, which do not fulfill Ney's rule, namely: H-Val-Ala-OH (68), H-Ala-Ala-Leu-OH (39) and H-Lys-Ala-OH (75). These peptides have a bitter taste, but their $Q$-values are below $1300 \mathrm{cal} \mathrm{res}^{-1}$.

Two other peptides, namely (46) and (47), cannot be taken into consideration because their bitter taste qualities were not determined in pure solutions.

However, inconsistent behavior in the peptides considered seems to be rare. Therefore the average hydrophobicity should be a useful assessment of the relationships 
between amino acid composition and bitter taste of peptides and protein hydrolysates. Although there is some evidence that bitterness increases with hydrophobicity, it would be an interesting topic for further research to investigate this point in some detail.

Finally it should be emphasized that this review is a restricted discussion of one aspect of a broad topic. It reports experimental results of chemical analyses of bitter tasting peptides. But the bitter taste is just one taste quality of peptides. Many peptides are described in the literature having an acid taste, a sweet taste, a brothy taste etc. And these peptides certainly differ in structure and in average hydrophobicity over a wide range. Information on these problems can be found elsewhere (Kirimura et al., 1969; Arai et al., 1973; Mazur et al., 1969; Noguchi et al., 1975).

\section{References}

Arai, S., Yamashita, M., Kato, H., and Fujimaki, M.: 1970, 'Applying Proteolytic Enzymes on Soybean. Part V. A Nondialyzable Bitter Peptide in Peptic Hydrolyzate of Soybean Protein and Its Bitterness in Relation to the Chemical Structure', Agr. Biol. Chem. 34, 729.

Arai, S., Yamashita, M., and Fujimaki, M.: 1972, 'Glutamyl Oligopeptides as Factors Responsible for Tastes of Proteinase-modified Soybean Protein', Agr. Biol. Chem. 36, 1253.

Arai, S., Yamashita, M., Noguchi, M., and Fujimaki, M.: 1973, 'Tastes of L-Glutamyl Oligopeptides in Relation to Their Chromatographic Properties', Agr. Biol. Chem. 37, 151.

Belitz, H. D. and Sparrer, D.: 1971, 'Isolierung eines bitteren Peptids aus einem chymotryptischen Caseinhydrolysat', Lebensm.-Wiss. u. Technol. 4, 131.

Belitz, H. D.: 1973, 'Struktur und Geschmack - Bitterpeptide', Z. Ernährungswiss. 12, (Suppl. 16) 150 (1973).

Bigelow, C. C.: 1967, 'On the Average Hydrophobicity of Proteins and the Relation between it and Protein Structure', J. Theor. Biol. 16, 187.

Carr, J. W., Loughheed, T. C., and Baker, B. E.: 1956, 'Studies on Protein Hydrolysis. IV. - Further Observations on the Taste of Enzymic Protein Hydrolysates', J. Sci. Food Agric. 7, 629.

Clegg, K. M., Lim, C. L., and Manson, W.: 1974, 'The Structure of a Bitter Peptide Derived from Casein by Digestion with Papain', J. Dairy Res. 41, 283.

Cserhati, T. and Hollo, J.: 1974, 'Ueber die Verwendung von Mikroben-Proteasen in der Milchindustrie. 6. Mitt. Untersuchung der Peptidbildung durch Labenzymprāparate', Nahrung 18, 625.

Dunnill, P.: 1965, 'How Proteins Acquire their Structure', Science Progr. 53, 609.

Fujimaki, M., Yamashita, M., Okazawa, Y., and Arai, S.: 1968a, 'Diffusable Bitter Peptides in Peptic Hydrolyzate of Soybean Protein', Agr. Biol. Chem. 32, 794.

Fujimaki, M., Kato, H., Arai, S., and Tamaki, E.: 1968b, 'Applying Proteolytic Enzymes on Soybean. Part 1. Proteolytic Enzyme Treatment of Soybean Protein and Its Effect to the Flavor', Food Technol. 22, 889.

Fujimaki, M., Yamashita, M., Okazawa, Y., and Arai, S.: 1970a, 'Applying Proteolytic Enzymes on Soybean. Part 3. Diffusable Bitter Peptides and Free Amino Acids in Peptic Hydrolyzate of Soybean Protein', J. Food Sci. 35, 215.

Fujimaki, M., Yamashita, M., Arai, S., and Kato, H.: 1970b, 'Enzymatic Modifications of Proteins in Foodstuffs. Part I. Enzymatic Proteolysis and Plastein Synthesis Application for Preparing Bland Protein-like Substances', Agr. Biol. Chem. 34, 1325.

Fujimaki, M., Arai, S., and Yamashita, M.: 1971a, 'Chemical Studies on Taste Peptides', in Annual Report 1971, Tanabe Amino Acid Research Foundation, Osaka, Japan, p. 51.

Fujimaki, M., Kato, H., Arai, S., and Yamashita, M.: 1971b, 'Application of Microbial Proteases to Soybean and Other Materials to Improve Acceptability, Especially through the Formation of Plastein', J. Appl. Bact. 34, 119.

Gordon, D. F. and Speck, M. L.: 1965, 'Bitter Peptide Isolated from Milk Cultures of Streptococcus Cremoris', Appl. Microbiol. 13, 537. 
Guigoz, Y. and Solms, J.: 1974, 'Isolation of a Bitter Tasting Peptide from "Alpkăse", a Swiss Mountain-Cheese', Lebensm.-Wiss. u. Technol. 7, 356.

Hamilton, J. S., Hill, R. D., and Van Leeuwen, H.: 1974, 'A Bitter Peptide from Cheddar Cheese', Agr. Biol. Chem. 38, 375.

Hill, R. D. and Van Leeuwen, H.: 1974, 'Bitter Peptides from Hydrolysed Casein Coprecipitate', Aust. J. Dairy Techn. 29, 32.

Hodges, R., Kent, S. B. H., and Richardson, B. C.: 1972, 'The Mass Spectra of Some Permethylated Acetylpeptides', Biochim. Biophys. Acta 257, 54.

Huber, L. and Klostermeyer, H.: 1974, 'Isolierung und Identifizierung eines Bitterstoffes aus Butterkåse', Milchwiss. 29, 449.

Ichikawa, K., Yamamoto, T., and Fukomoto, J.: 1959, 'Bitter-tasting Peptides Produced by Proteinases. I. The Formation of Bitter-tasting Peptides by the Neutral Proteinase of Bacillus Subtilis and Isolation of the Peptides', J. Agric. Chem. Soc. Japan 33, 1044, Ref.: Chem. Abstr. 57, 15465 (1962).

Kirimura, J., Shimizu, A., Kimizuka, A., Ninomiya, T., and Katsuya, N.: 1969, 'The Contribution of Peptides and Amino Acids to the Taste of Foodstuffs', J. Agr. Food Chem. 17, 689.

Matoba, T., Hayashi, R., and Hata, T.: 1970, 'Isolation of Bitter Peptides from Tryptic Hydrolysate of Casein and their Chemical Structure', Agr. Biol. Chem. 34, 1235.

Matoba, T. and Hata, T.: 1972, 'Relationship between Bitterness of Peptides and Their Chemical Structures', Agr. Biol. Chem. 36, 1423.

Mazur, R. H., Schlatter, J. M., and Goldkamp, A. H.: 1969, 'Structure - Taste Relationships of Some Dipeptides', J. Am. Chem. Soc. 91, 2684.

Mercier, J.-C., Grosclaude, F., and Ribadeau-Dumas, B.: 1971, 'Structure primaire de la caséine $\alpha_{11}$-bovine. Sequence complète', Eur. J. Biochem. 23, 41.

Minamiura, N., Matsumara, Y., Fukumoto, J., and Yamamoto, T.: 1972a, 'Bitter Peptides in Cow Milk Digest with Bacterial Proteinase. Part 1. Isolation and Determination of Amino Acid Sequence of a Bitter Peptide', Agr. Biol. Chem. 36, 588.

Minamiura, N., Matsumara, Y., and Yamamoto, T.: 1972b, 'Bitter Peptides in the Casein Digests with Bacterial Proteinase. Part II. A Bitter Peptide Consisting of Tryptophan and Leucine', $J$. Biochem. 72, 841 .

Murray, T. K. and Baker, B. E.: 1952, 'Studies on Protein Hydrolysis. Part I. - Preliminary Observations on the Taste of Enzymic Protein-Hydrolysates', J. Sci. Food Agric. 3, 470.

Nemethy, G.: 1967, 'Hydrophobe Wechselwirkungen', Angew. Chem. 79, 260.

Ney, K. H.: 1971, 'Voraussage der Bitterkeit von Peptiden aus deren Aminosalurezusammensetzung', Z. Lebensm. Unters.-Forsch. 147, 64.

Ney, K. H.: 1972, 'Aminosåure-Zusammensetzung von Proteinen und die Bitterkeit ihrer Peptide', Z. Lebensm. Unters.-Forsch. 149, 321.

Noguchi, M., Arai, S., Yamashita, M., Kato, H., and Fujimaki, M.: 1975, 'Isolation and Identification of Acidic Oligopeptides Occurring in a Flavor Potentiating Fraction from a Fish Protein Hydrolysate', J. Agr. Food Chem. 23, 49.

Nozaki, Y. and Tanford, C.: 1971, 'The Solubility of Amino Acids and Two Gycine Peptides in Aqueous Ethanol and Dioxane Solutions. Establishment of a Hydrophobicity Scale', J. Biol. Chem. 246, 2211.

Pelissier, J.-P., Mercier, J.-C., and Ribadeau-Dumas, B.: 1974, 'Étude de la protéolyse des caséines $\alpha_{\sharp 1}$ et $\beta$ bovines par la présure. Spécificité d'action. Peptides amers libérés', Ann. Biol. anim. Bioch. Biophys. 14, 343.

Petritschek, A., Lynen, F., and Belitz, H. D.: 1972, 'Untersuchungen über Bitterpeptide. II. Auftreten von Bittergeschmack in enzymatischen Hydrolysaten verschiedener Proteine', Lebensm.-Wiss. $u$. Technol. 5, 77.

Pickenhagen, W.: 1974, 'Le principe amer du cacao', Thèse, Université de Paris-Sud, Centre d'Orsay. Raadsveld, C. W.: 1953, 'Bitter Compounds from Chese', Proc. 13th intern. Dairy Congr. $2,676$.

Ribadeau-Dumas, B., Brignon, G., Grosclaude, F., and Mercier, J. C.: 1972, 'Structure primaire de la caséine $\beta$ bovine. Stquence complète', Eur. J. Biochem. 25, 505.

Richardson, B. C. and Creamer, L. K.: 1973, 'Casein Proteolysis and Bitter Peptides in Cheddar Cheese', N.Z. J. Dairy Sci. Techn. 8, 46.

Shiba, T. and Nunami, K.: 1974, 'Structure of a Bitter Peptide in Casein Hydrolysate by Bacterial Proteinase', Tetrahedron Letters 6, 509. 
Shiraishi, H., Okuda, K., Sato, Y., Yamaoka, N., and Tuzimura, K.: 1973, 'Taste of Proline-containing Peptides', Agr. Biol. Chem. 37, 2427.

Sparrer, D. and Belitz, H. D.: 1975, 'Bittere Peptide aus Casein nach Hydrolyse mit a-Chymotrypsin and Trypsin', Z. Lebensm. Unters.-Forsch. 157, 197.

Sullivan, J. J., Kieseker, F. G., and Jago, G. R.: 1971, 'The Effect of pH and Starter Cultures on the Bitterness of Peptide Extracts of a Tryptic Digesto of Casein', Aust. J. Dairy Techn. 26, 111.

Takahashi, K., Tadenuma, M., Kitamoto, K., and Sato, S.: 1974, 'L-Prolyl-L-Leucine Anhydride. A Bitter Compound Formed in Aged Sake', Agr. Biol. Chem. 38, 927.

Tanford, C.: 1962, 'Contribution of Hydrophobic Interactions to the Stability of the Globular Conformation of Proteins', J. Am. Chem. Soc. 84, 4240.

Tanford, C.: 1972, 'The Hydrophobic Effect', Wiley Interscience Publ. Co., New York.

Wieser, H. and Belitz, H. D.: Jahresbericht 1973, Deutsche Forschungsanstalt für Lebensmittelchemie, Munich, p. 24.

Yamashita, M., Arai, S., and Fujimaki, M.: 1969, 'Applying Proteolytic Enzymes on Soybean. Part IV. A Ninhydrin-Negative Bitter Peptide in Peptic Hydrolyzate of Soybean Protein', Agr. Biol. Chem. 33, 321.

Yamashita, M., Arai, S., Matsuyama, J., Kato, H., and Fujimaki, M.: 1970, 'Enzymatic Modification of Proteins in Foodstuffs. Part IV. Bitter Dipeptides as Plastein-building Blocks Debittering of Peptic Proteolyzate with a-Chymotrypsin', Agr. Biol. Chem. 34, 1492.

Zvyagintsev, V. I., Buzov, I. P., Belov, A. N., and Novgorodova, N. S.: 1972, 'Study of Certain Properties of Bitter Decomposition Products of Casein and Investigation of the Possibility of their Hydrolysis', Prikl. Bioklim. i Mikrobiol. 8, 287, Ref.: APBMAC 8, 242. 